\title{
KEAMPUAN BERFIKIR KREATIF SISWA DITINJAU DARI MINAT BELAJAR (Studi Komparasi pada Mata Pelajaran Produk Kreatif dan Kewirausahaan di Kelas XI Akuntansi SMK Medikacom Bandung)
}

\author{
${ }^{1}$ Veri Aryanto Sopiansah, ${ }^{2}$ Saiful Almujab \\ 1, Sekolah Pascasarjana Universitas Pendidikan Indonesia \\ 2, Universitas Pasundan Bandung \\ Email: veriaryanto@gmail.com
}

\begin{abstract}
Tujuan dari penelitian ini untuk mengetahui perbedaan kemampuan berfikir kreatif siswa pada kategori minat belajar tinggi dan minat belajar rendah. Metode penelitian yang digunakan adalah metode komparasi dengan analisis data menggunakan uji t (one sampel t-tes) dengan uji hipotesis ANOVA. Populasi yang digunakan siswa juruan akuntansi SMK Medikacom dengaan sampel kelas XI AK A dan B. Penelitian ini dibagi dalam dua kelompok siswa, yaitu kelompok siswa dalam kategori minat belajar tinggi dan siswa dalam kategori minat belajar rendah. Berdasarkan hasil pengujian hipotesis, ditemukan hasil bahwasanya terdapat perbedaan kemampuan berfikir kreatif siswa dalam kategori minat belajar tinggi dan siswa dalam kategori minat belajar rendah. Pembelajaran yang dilakukan guru harus dapat memperhatiakan tingkat minat belajar siswanya karna itu akan mempengaruhi proses dan hasil belajar, termasuk kemampuan berfikir salah satunya berfikir kreatif.

Kata kunci: Berfikir kreatif, Hasil belajar, Minat belajar.

\section{PENDAHULUAN}

Tantangan dan peluang industri 4.0 mendorong inovasi dan kreasi pendidikan. Pemerintah perlu meninjau relevansi antara pendidikan kejuruan dan pekerjaan untuk merespon perubahan, tantangan, dan peluang era industri 4.0 dengan tetap memperhatikan aspek kemanusiaan (humanities). Untuk menghadapi tantangan revolusi industry 4.0 diperlukan Pendidikan yang bermutu dan sesuai perkembangan abad 21. P21 (Partnership for 21 st Century Learning) mengembangkan framework pembelajaran di abad 21 yang menuntut peserta didik untuk memiliki keterampilan, pengetahuan dan kemampuan dibidang teknologi, media dan informasi, keterampilan pembelajaran dan inovasi serta keterampilan hidup dan karir. Framework ini juga menjelaskan tentang keterampilan, pengetahuan dan keahlian yang harus dikuasai agar siswa dapat sukses dalam kehidupan dan pekerjaannya.
\end{abstract}

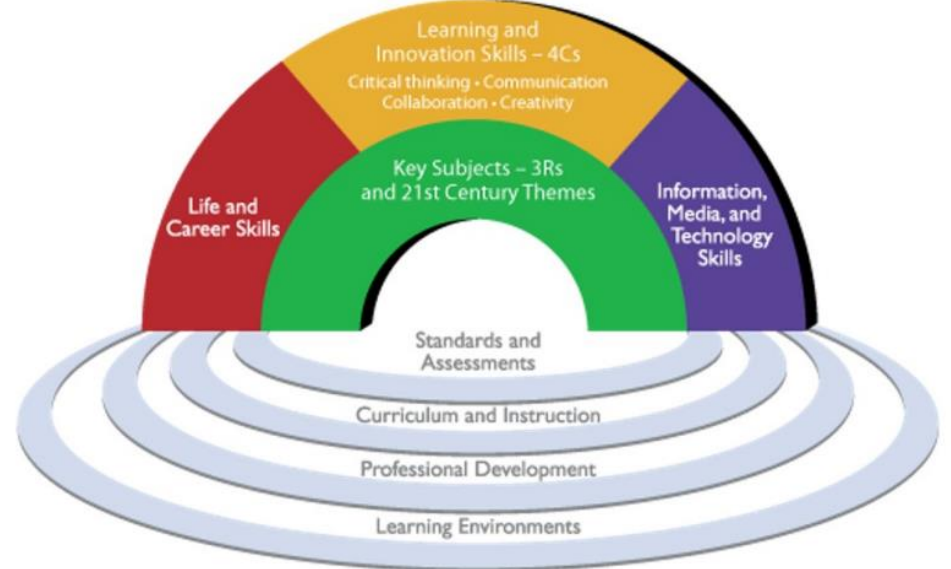

Gambar Error! No text of specified style in document. Core Subject 21st Century Skills 
Muatan pembelajaran abad 21 harus selalu menyesuaikan dengan perubahan termasuk di era industri 4.0. Muatan pembelajaran diharapkan mampu memenuhi keterampilan abad 21 (21st century skills); 1) pembelajaran dan keterampilan inovasi meliputi penguasan pengetahuan dan keterampilan yang beraneka ragam, pembelajaran dan inovasi, berpikir kritis dan penyelesaian masalah, komunikasi dan kolaborasi, dan kreatifitas dan inovasi, 2) keterampilan literasi digital meliputi literasi informasi, literasi media, dan literasi ICT, 3) karir dan kecakapan hidup meliputi fleksibilitas dan adaptabilitas, inisiatif, interaksi sosial dan budaya, produktifitas dan akuntabilitas, dan kepemimpinan dan tanggung jawab (Trilling, 2009)

Sejalan dengan hal itu, Kemdikbud merumuskan bahwa paradigma pembelajaran abad 21 menekankan pada kemampuan peserta didik dalam mencari tahu dari berbagai sumber, merumuskan permasalahan, berpikir analitis dan kerjasama serta berkolaborasi dalam menyelesaikan masalah (Litbang, 2013). Adapun penjelasan mengenai framework pembelajaran abad ke-21 salah satunya adalah Kemampuan berpikir kritis dan pemecahan masalah (Critical-Thinking and Problem-Solving Skills), mampu berfikir secara kritis, lateral, dan sistemik, terutama dalam konteks pemecahan masalah agar memiliki kemampuan mencipta dan membaharui (Creativity and Innovation Skills), mampu mengembangkan kreativitas yang dimilikinya untuk menghasilkan berbagai terobosan yang inovatif

\section{Tavel 1}

\section{Keterampilan belajar dan berinovasi}

\section{Keterampilan Abad 21 Keterampilan Belajar dan Berinovasi}

\section{Deskripsi}

1. Berpikir kritis dan mengatasi masalah.

2. Komunikasi dan kolaborasi

3. Kreativitas dan inovasi

Sumber: (Trilling, 2009)

Pola pembelajaran dewasa ini menuntut keaktifan dan kreativitas siswa mengolah data atau informasi yang diberikan guru selama proses kegiatan belajar mengajar agar terjadi pengonstruksian pengetahuan secara bermakna. Oleh karena itu, dibutuhkan kemampuan untuk berpikir (Kusumaningtias, Zubaidah, \& Indriwati, 2013). Pada proses pembelajaran perlu dikembangkan keterampilan berpikir yang merupakan suatu aktivitas mental untuk memperoleh pengetahuan, berdasarkan prosesnya berpikir dapat dikelompokkan kedalam berpikir dasar dan berpikir kompleks, proses berpikir kompleks yang disebut berpikir tingkat tinggi mencakup empat macam, yaitu pemecahan masalah, pengambilan keputusan, berpikir kritis dan berpikir kreatif (Costa dalam Wiyono et al., 2009).

Kreativitas adalah kemampuan untuk memberikan gagasan-gagasan baru dan menerapkannya dalam pemecahan masalah meliputi baik ciri-ciri aptitude seperti kelancaran (fluency), keluwesan (flexibility), dan keaslian (originality) dalam pemikiran, maupun ciri-ciri non aptitude, seperti rasa ingin tahu, senang mengajukan pertanyaan dan selalu ingin mencari pengalaman-pengalaman baru (Filsaime, 2008 ). Kreativitas adalah kemampuan untuk mengkombinasikan, memecahkan atau menjawab masalah, dan cerminan kemampuan operasional anak kreatif (Utami, 2009). Menurut Lindren dalam (Martinis, 2008) Berpikir kreatif yaitu memberikan macam-macam kemungkinan jawaban atau pemecahan masalah berdasarkan informasi yang diberikan dan mencetuskan banyak gagasan terhadap suatu persoalan. 
Tabel 2

Pencapaian Indikator Kemampuan Berpikir Kreatif Siswa

\begin{tabular}{lccccc}
\hline \multirow{2}{*}{ Kelas } & $\begin{array}{c}\text { Jumlah } \\
\text { Siswa }\end{array}$ & \multicolumn{3}{c}{ Indikator Kemampuan Berpikir Kreatif (\%) } \\
\cline { 3 - 6 } & $\begin{array}{c}\text { Berpikir } \\
\text { Luwes } \\
\text { (Flexible) }\end{array}$ & $\begin{array}{c}\text { Berpikir } \\
\text { Lancar } \\
\text { (Fluency) }\end{array}$ & $\begin{array}{c}\text { Berpikir } \\
\text { Orisinal }\end{array}$ & $\begin{array}{c}\text { Berpikir } \\
\text { Terperinci } \\
\text { (Elaborasi) }\end{array}$ \\
\hline XI AK A & 36 & 41,75 & 40,80 & 32,77 & 38,33 \\
XI AK B & 36 & 41,80 & 39,33 & 34,50 & 35,20 \\
XI AK C & 36 & 40,87 & 35,67 & 34,50 & 31,23 \\
XI AK D & 36 & 41,75 & 40,80 & 32,77 & 38,33 \\
\multicolumn{2}{r}{ Rata-Rata } & 41,47 & 38,36 & 33,92 & 34,92 \\
\hline
\end{tabular}

Sumber : Pra Penelitian, data diolah

Pengolahan data pada Tabel di atas, merupakan hasil dari jumlah siswa menjawab benar pada setiap item soal dibagi jumlah siswa dikali $100 \%$. Setiap indikator berpikir kreatif menunjukan bahwa rata-rata kemampuan siswa dalam berpikir kreatif masih di bawah $50 \%$. Hal tersebut menunjukkan tingkat kemampuan berpikir kreatif yang masih rendah.

Pentingnya berpikir kreatif tertera dalam Sistem Pendidikan Nasional No 20 Tahun 2003 yang intinya antara lain adalah melalui pendidikan diharapkan dapat mengembangkan potensi peserta didik agar menjadi manusia yang bertakwa, berakhlak mulia, cakap, kreatif, juga mandiri. Namun pada kenyataanya, "pendidikan kita masih sangat lemah dalam proses pembelajaran" (Sanjaya, 2010). Dalam proses pembelajaran, anak kurang didorong untuk mengembangkan kemampuan berpikir. Selain itu, dengan adanya kenyataan bahwa sebagian besar siswa tidak dapat mengembangkan kemampuan berpikir kreatifnya. Sehingga tugas guru adalah membantu siswa mencapai tujuannya, maksudnya guru lebih banyak berurusan dengan strategi daripada memberi informasi, tetapi justru siswa yang aktif mencari informasi. Tugas guru mengelola kelas sebagai sebuah tim yang bekerja bersama untuk menemukan sesuatu yang baru bagi siswa. Sesuatu yang baru datang dari menemukan sendiri bukan dari apa kata guru.

Rendahnya prestasi belajar siswa terjadi sebagai akibat dari pembelajaran yang dilakukan oleh guru-guru. Agar siswa dapat menjadi seorang yang literasi sains dan memiliki sikap ilmiah, siswa harus memiliki keterampilan berpikir tingkat tinggi. Untuk mengatasi permasalahan di atas, siswa harus memiliki keterampilan berpikir tingkat tinggi (Redhana, Agung, Sudiatmika, \& Artawan, 2009). Untuk mengukur kemampuan berpikir peserta didik dapat dilihat dari perolehan nilai peserta didik dan dari soal-soal yang digunakan (Edora, 2014), berikut tabel mengenai hasil belajar siswa yang tergolong rendah:

Tabel 3

Rata-rata Hasil Ujian Akhir Semester Genap 2017/2018

\begin{tabular}{cccc}
\hline No & Kelas & Nilai Rata-Rata & KKM \\
\hline 1 & X Akuntansi 1 & 70,56 & 75 \\
2 & X Akuntansi 2 & 72,91 & 75 \\
3 & X Akuntansi 3 & 69,66 & 75 \\
4 & X Akuntansi 4 & 71,66 & 75 \\
\hline
\end{tabular}

Sumber: Hasil UAS Produktif dan Kewirausahaan tahun pelajaran 2017-2018 
Tabel 4

Hasil Analisis Soal Ujian Akhir Semester Genap 2017/2018

\begin{tabular}{lllllll}
\hline Proses Kognitif & C1 & C2 & C3 & C4 & C5 & C6 \\
\hline Jumlah & 11 & 31 & 5 & 3 & - & - \\
\hline
\end{tabular}

Sumber: Olah data pra penelitian

Untuk meningkatkan kemampuan berpikir kreatif, proses pembelajaran yang digunakan adalah proses pembelajaran bermakna (joyfull learning) dimana proses pembelajaran harus difokuskan pada mengkosntruksi pengetahuan. Sebagaimana diungkapkan oleh (Anderson, 2010) bahwa:

"A focus on meaningful learning is consistent with the view of learning as knowlwdge construction, in which student seek to make sense of their experiences. In constructivist learning, students engage in active cognitive processing, as paying attention into coherent representation, and mentally organizing incoming information with existing knowledge".

Guru tidak harus selalu menyampaikan materi, tetapi guru harus merangsang pemikiran siswa dengan pertanyaan-pertanyaan yang penuh dengan selidik, memancing penalaran, dan memberikan petunjuk yang merangsang siswa untuk menyimpulkan. Cara inilah yang disebut dengan membangun pengetahuan sendiri (kostruktivisme).

Salah satu faktor yang menentukan kualitas pendidikan adalah diselenggarakannya pembelajaran yang dirancang secara sistematis sesuai kaidah-kaidah pembelajaran yang efektif. Karena pembelajaran adalah merupakan sistem, maka perancangan pembelajaran seharusnya dilakukan secara sistematik (menggunakan pendekatan sistem), faktor keberhasilan proses pembelajaran banyak ditentukan oleh minat belajar siswa, minat sebagai pernyataan psikis yang menunjukkan adanya pemusatan perhatian terhadap suatu materi pelajaran karena obyek tersebut menarik bagi dirinya. Minat belajar adalah kecenderungan hati yang tinggi terhadap suatu gairah keinginan un-tuk suatu perubahan yang terjadi pada seseorang dalam melaksanakan kegiatan (belajar) amat bergantung dari kapasitas yang dimiliki. Pemusatan perhatian dalam proses pembelajaran sangat diperlukan, karena kehadiran minat belajar dalam pribadi seseorang akan merangsang keinginan untuk belajar yang lebih besar (Muldayanti, 2013).

Berdasarkan penjelasan di atas maka penulis akan mengajukan penelitian dengan judul "Pengaruh problem based learning dan discovery learning terhadap kemampuan berfikir kreatif siswa dengan minat belajar sebagai variabel moderator (Studi eksperimen faktorial pada siswa kelas XI Akuntansi di SMKN 3 bandung mata pelajaran produk kreatif dan kewirausahaan)".

\section{LANDASAN TEORI}

Teori yang melandasi pengembangan kreativitas dapat di bedakan menjaditiga (Utami, 2009), yaitu: 1) Teori Psikoanalisis Freud Sigmund, Ernt Kris dan Carl Jung, 2) Teori Humanistik Maslow dan Rogers, 3) Teori Cziksentmihalyi, menurut Presseisen keterampilan berpikir dapat dikelompokkan menjadi dua kelompok, yaitu: keterampilan berpikir dasar dan keterampilan berpikir kompleks atau keterampilan berpikir tingkat tinggi (higher order thinking). Sedangkan menurut Novak proses berpikir dasar merupakan gambaran dari proses berpikir rasional yang mengandung sekumpulan proses mental dari yang sederhana menuju yang kompleks (Almujab, 2015).

Menurut Martinis (Martinis, 2008), Keterampilan berpikir kreatif (creative thinking) merupakan keterampilan individu dalam menggunakan proses berpikirnya untuk menghasilkan gagasan baru, konstruktif berdasarkan konsep-konsep dan prinsip-prinsip yang rasiornal maupun persepsi, dan instuisi individu. Torrance dalam (Filsaime, 2008 ) mengemukakan empat karakteristik berpikir kreatif yaitu:

a. Berpikir lancar (kelancaran), yaitu kemampuan untuk menciptakan segudang ide. 
b. Berpikir luwes (Keluwesan/fleksibelitas), yaitu menggambarkan kemampuan seseorang individu untuk memandang sebuah masalah secara instan dari berbagai perspektif.

c. Berpikir orisinil (orisinalitas), merupakan kategori orisinalitas mengacu pada keunikan dari respon apapun yang diberikan. orisinilitas yang ditujukan oleh sebuah respon yang tidak biasa, unik dan jarang terjadi.

Berpikir terperinci (elaborasi) merupakan kemampuan untuk menguraikan sebuah obyek tertentu. Elaborasi adalah jembatan yang harus dilewati oleh seseorang untuk mengkonsumsikan ide "kreatif'-nya kepada masyarakat.

Minat merupakan faktor penting terhadap keberhasilan belajar siswa karena siswa yang memiliki minat terhadap suatu hal akan cenderung bersungguh-sungguh berbeda dengan siswa yang tidak memiliki minat akan cenderung berleha-leha, dengan konsep pembelajaran yang menuntun pemikiran kreatif siswa, ketika proses pembelajaran sesuai dengan tujuan maka terdapat pencapaian tingkat berfikir kreatif siswa dapat dikatakan berhasil dan dipengaruhi oleh minat belajarnya.

Minat sebagai kecenderungan dalam diri seorang untuk tertarik pada suatu objek. dalam minat terdapat unsur penting yang berupa rasa tertarik/senang, perhatian, dan keinginan untuk beraktivitas di dalamnya. Jadi seseorang yang mempunyai minat dalam diri seorang tersebut terdapat pemikiran rasa senang terhadap objek yang di minatinya. Seorang yang berminat terhadap suatu aktivitas akan memperhatikan aktivitas itu secara konsisten dengan rasa senang. Pada dasarnya minat adalah suatu kegiatan individu untuk meraih atau mencapai suatu sasaran, sehingga minat besar sekali terhadap pencapaian tujuan seseorang.

Dalam penelitian ini minat belajar akan dilihat dengan kategori tinggi dan kategori rendah. Siswa yang memiliki Minat belajar tinggi akan cenderung tekun, ulet, semangat dalam belajar, pantang menyerah dan senang menghadapi tantangan. Mereka memandang setiap hambatan belajar sebagai tantangan yang harus mampu diatasi. Minat Belajar Rendah Seorang yang memiliki minat rendah tidak ada ketertarikan terhadap suatu objek. Siswa yang memiliki tingkat minat belajar belajar rendah, umumnya akan malas belajar, cenderung menghindar dari tugas dan pekerjaan. Akan merasa senang jika guru tidak hadir, dan tidak ada upaya untuk belajar mandiri menambah pengetahuan baik melalui bertanya pada teman maupun membaca literatur. Jika ada tugas pekerjaan rumah atau tugas lainnya dikerjakan hanya sekedar untuk memenuhi dan menggugurkan kewajiban saja, tidak mempedulikan bahwa tugas tersebut bermakna atau tidak. Siswa yang memiliki minat belajar rendah dibutuhkan peranan guru yang tinggi dalam menyemangati belajar (Tambunan, 2016).

Dengan demikian minat belajar siswa dapat mempengaruhi dan meningkatkan hasil belajar termasuk hasil belajar dengan menekankan kemampuan berfikir kreatif siswa, siswa yang memiliki minat belajar tinggi cenderung lebih mudah untuk meningkatkan kemampuan derfikir kreatifnya dibandingkan siswa yang memiliki minat belajar rendah. Pendapat ini sejalan dengan hasil penelitian (Tambunan, 2016) bahwa terdapat pengaruh minat belajar terhadap kemampuan berpikir kreatif siswa, Kemampuan bepikir kreatif siswa yang memiliki minat belajar tinggi lebih baik secara signifikan dibandingkan dengan siswa yang memiliki minat belajar rendah. Fenomena ini menunjukkan bahwa kemampuan berpikir kreatif siswa akan meningkat jika siswa memiliki minat terhadap mata pelajaran.

Konsep dalam penelitian ini adalah untuk mengetahui peningkatan kemampuan berfikir kritis siswa pada siswa yang memiliki minat belajar tinggi da siswa yang memiliki minat belajar rendah, serta untuk membandingkan pengaruh dari keduanya terhadap berfikir kreatif. 


\section{METODOLOGI}

Metode penelitian yang digunakan adalah metode komparasi hasil ujian Penelitian ini dibagi dalam dua kelompok yaitu kelompok siswa yang memilki kategori minat tinggi dan siswa yang memiliki kategori minat rendah, kemudian dilakukan analisis untuk melihat tingkat berfikir kreatif pada kedua kategori minat tersebut.

Desain penelitian yang digunakan adalah sebagai berikut:

\section{Tabel 5}

Design Compparison

\begin{tabular}{cc}
\hline Minat Belajar & Jumlah \\
\hline Minat Belajar Tinggi (B) & A \\
Minat Belajar rendah (B) & B \\
\hline
\end{tabular}

\section{Total}

Populasi dalam penelitian ini adalah seluruh siswa kelas XI Akuntansi SMK Medikacom Bandung pada tahun ajaran 2018/2019. Alasan dipilihnya siswa kelas XI dalam penelitian ini dikarenakan siswa kelas XI telah diasumsikan memiliki pengetahuan yang cukup, siap untuk menyelesaikan soal-soal yang menuntut kemampuan berpikir kritis, tidak terlalu terganggu dengan aktivitas-aktivitas pendidikan seperti persiapan serta pelaksanaan ujian nasional.

Teknik pengambilan sampel yang akan digunakan dalam penelitian ini adalah teknik purposive sampling. Purposive sampling dikenal juga dengan sampling pertimbangan. Purposive sampling ialah teknik sampling yang digunakan peneliti jika peneliti mempunyai pertimbangan-pertimbangan tertentu di dalam pengambilan sampelnya atau penentuan sampel untuk tujuan tertentu. Adapun sampel dalam penelitian ini adalah siswa kelas XI Akuntansi A, dan siswa kelas XI Akuntansi D SMK Medikacom Bandung pada tahun ajaran 2018/2019.

Teknik pengumpulan data yang digunakan untuk menentukan kemampuan berfikir kreatif siswa adalah tekhnik tes objektif berfikir kreatif, sedangkan untuk menentukan tingkat tinggi dan rendahnya minat belajar siswa akan menggunakan quisioner, tekhnik pengumpulan data ini dilakukan pasca treatment pembelajaran diskusi.

Pengumpulan data tentang kemampuan berfikir kreatif dalam penelitian ini akan menggunakan tes tulis kemampuan berpikir kreatif yang berbentuk objektif (soal) berdasarkan teori yang dikemukakan Munandar (2009) tentang indikator kemampuan berfikir kreatif yaitu 1) Keterampilan berpikir lancar (fluency), 2) Keterampilan berpikir luwes (fleksibility), 3) Keterampilan berpikir orisinal, 4) Keterampilan merinci (elaboration). Sedangkan untuk mengukkur minat belajar akan menggunakan kuisioner dengan memperhatikan indikator minat belajar menurut (Herlina, 2010), bahwa untuk mengetahui berapa besar minat belajar siswa, dapat diukur melalui: 1) Kesukaan, 2) Ketertarikan, 3) Perhatian, 4) Keterlibatan.

Kuisioner akan disebarkan sebelum pembelajaran untuk mengetahui minat belajar siswa. Tes diadakan setelah diselenggarakannya kegiatan treatmen pembelajaran diskusi. Soal yang diberikan merupakan soal mata pelajaran Akuntansi keuangan Lembaga tentang konsep akuntansi di pemerintah daerah. Setelah terkumpul data penelitian, secara singkat dapat dijelaskan tekhnik pengolahan data yaitu (1) Menghitung tiap lembar jawaban tes peserta didik berdasarkan jawaban peserta didik yang benar, (2)menghitung hasil kuisioner minat belajar dan mengkategorikan dalam minat tinggi dan rendah, (3) Melakukan Uji Normalitas, (6) Melakukan Uji Homogenitas, (6) Uji Hipotesis Penelitian. Analisis data penelitian akan menggunakan aplikasi SPSS 24 for windows.

\section{HASIL DAN PEMBAHASAN}

Berdasarkan hasil pengujian validitas, diketahui bahwa semua item dalam penelitian ini dinyatakan valid baik item soal maupun kuisioner, karena nilai t-hitung lebih besar dari t-tabel, yaitu t-tabel $>0,468$ dengan menggunakan taraf signifikan $\alpha=0,05$. Sedangkan pengujian 
reabilitas soal bertujuan melihat ketetapan soal tersebut menggunakan rumus Spearman Brown, nilai reabilitas yang diperoleh dari hasil perhitungan yaitu sebesar 0,843 untuk tes dan 0,776 untuk kuisioner. Hasil ini menandakan soal berada dalam kategori sangat tinggi dan dapat digunakan dalam penelitian. Langkah berikutnya peneliti melakukan uji normalitas dimana variabel Minat dan berfikir kreatif menunjukan nilai signifikasi $200^{*}$ sehingga dapat disimpulkan bahwa variabel yang telah di uji berdistribusi normal. Uji homogenitas untuk mengetahui kedua kelas sampel mempunyai varians yang homogen atau tida dilakukan dengan uji statistik levene's test yang diolah menggunakan SPSS (Statistical product and Service Solution), 21.0 dengan taraf signifikansi 5\%. Dari hasil analisis dapat dilihat bahwa hasil tes pada kedua kelas berdistribusi normal, $(p<0,05)$. Setelah itu penelitian ini menghitung rata-rata kemampuan berfikir kreatif siswa pada kedua kategori minat belajar. Hasil analisis data adalah sebagai berikut

Tabel 6

Deskriptif Statistik Kemampuan Berfikir Kreatif

\begin{tabular}{|c|c|c|c|c|c|}
\hline \multicolumn{3}{|c|}{ Berfikir Kreatif } & \multicolumn{3}{|c|}{ Minat Belajar } \\
\hline Interval & Frekuensi & Persentase & Interval & Frekuensi & Persentase \\
\hline $4-5$ & 2 & $3 \%$ & $38-43$ & 6 & 9 \\
\hline $6-7$ & 6 & $9 \%$ & $44-49$ & 2 & 3 \\
\hline $8-9$ & 6 & $9 \%$ & $50-55$ & 11 & 16 \\
\hline $10-11$ & 11 & $16 \%$ & $56-61$ & 27 & 40 \\
\hline $12-13$ & 22 & $32 \%$ & $62-67$ & 16 & 24 \\
\hline $14-15$ & 17 & $25 \%$ & $68-73$ & 4 & 6 \\
\hline $16-17$ & 4 & $6 \%$ & $74-79$ & 2 & 3 \\
\hline Total & \multicolumn{2}{|c|}{68} & \multicolumn{3}{|c|}{68} \\
\hline Mean & \multicolumn{2}{|c|}{13,0735} & \multicolumn{3}{|c|}{58,2500} \\
\hline Median & \multicolumn{2}{|c|}{12,0000} & \multicolumn{3}{|c|}{59,0000} \\
\hline Std. Deviation & \multicolumn{2}{|c|}{3,05305} & \multicolumn{3}{|c|}{8,05091} \\
\hline Minimum & \multicolumn{2}{|c|}{4,00} & \multicolumn{3}{|c|}{38,00} \\
\hline Maximum & \multicolumn{2}{|c|}{17,00} & \multicolumn{3}{|c|}{77,00} \\
\hline
\end{tabular}

Berdasarkan deskripsi di atas dapat disimpulkan bahwa kemampuan berfikir kreatif siswa telah menunjukan rata-rata lebih dari setengahnya, jika skor dikonversikan dalam skala 100 sesuai niilai belajar yang saat ini diterapkan disekolah, maka skor kemampuan berfikir kreatif siswa rata-rata telah melewati kriteria ketuntasan minimal. Skor terbanyak siswa berada pada rentang 12-13 jawaban benar, sedangkan skor paling sedikit yang didaapat siswa beraada pada rentang 4-5.

Berdasarkan deskripsi di atas dapat disimpulkan bahwa minat belajar siswa telah menunjukan rata-rata lebih dari setengahnya, skor terbanyak siswa berada pada rentang 5661, sedangkan skor paling sedikit yang didaapat siswa beraada pada rentang 44-49 dan 7479. Berdasarkan kesimpulan ini maka selaanjutnya minat belajar akan dikategorikan kedalam minat tinggi dan minat rendah, dengan menggunakan nilai tengah (median) sebagai batas minat tinggi dan minat rendah, siswa yang memiliki nilai minat antara 38 (skor terkecil) sampai 58,5 anrtinya skor yang didaapat lebih kecil dari pada nilai tengah (skor minat<59) maka dikategorikan minat belajar siswa rendah, sedangkan siswa yang memiliki nilai minat antara 39 (nilai tengah) sampai 77 anrtinya skor yang didaapat lebih besar dari pada nilai tengah (skor minat>59) maka dikategorikan minat belajar siswa tinggi.

Setiap factor yang digunakan dalam penelitian ini dianalisis berdasarkan rata-rata kemampuan berfikir kreatif dari soal yang diberikan. Berikut ini hasil rata-rata kemampuan berfikir kreatif siswa: 
Tabel 7

Rata-rata Kemampuan Berfikir Kreatif Siswa

\begin{tabular}{|c|c|c|c|c|}
\hline \multicolumn{5}{|c|}{ Dependent Variable: Kemampuan Berfikir Kreatif } \\
\hline Kelas & $\begin{array}{l}\text { Kategori } \\
\text { Minat }\end{array}$ & Mean & $\begin{array}{c}\text { Std. } \\
\text { Deviation }\end{array}$ & $\mathbf{N}$ \\
\hline \multirow[t]{3}{*}{ XI AK A } & Minat Tinggi & 15,4615 & 1,79401 & 26 \\
\hline & Minat Rendah & 13,1250 & 2,94897 & 8 \\
\hline & Total & 14,9118 & 2,30109 & 34 \\
\hline \multirow[t]{3}{*}{ XI AK B } & Minat Tinggi & 14,1538 & 1,06819 & 13 \\
\hline & Minat Rendah & 9,4286 & 3,02608 & 21 \\
\hline & Total & 11,2353 & 3,37602 & 34 \\
\hline \multirow[t]{3}{*}{ Total } & Minat Tinggi & 15,0256 & 1,69344 & 39 \\
\hline & Minat Rendah & 10,4483 & 3,39733 & 29 \\
\hline & Total & 13,0735 & 3,41339 & 68 \\
\hline
\end{tabular}

Berdasarkan tabel di atas, dapat dilihat total rata-rata kemampuan berfikir kreatif siswa dilihat dari minat belajar sebesar 13,0735 , total ini didapat dari total rata-rata kemampuan berfikir kreatif pada kategori siswa yang memiliki minat tinggi sebesar 15,0256 dan pada kategori siswa yang memiliki minat rendah sebesar 10,4483. Secara lebih rinci kemampuan berfikir kreatif pada kategori siswa yang memiliki minat tinggi pada kelas XI AK A sebesar 15,4615 dan dengan pada kelas XI AK B sebesar 14,1538. Sedangkan kemampuan berfikir kreatif pada kategori siswa yang memiliki minat rendah pada kelas XI AK A sebesar 13,1250 dan pada kategori siswa yang memiliki minat rendah pada kelas XI AK B sebesar 9,4286.

Berdasarkan interpretasi di atas dapat juga disimpulkan bahwa kemampuan berfikir kreatif siswa yang memiliki minat belajar tinggi jauh lebih besar dibandingkan dengan rata-rata kemampuan berfikir kreatif siswa yang memiliki minat belajar rendah.

Untuk lebih menguatkan temuan penelitian ini dilakukan pengujian komparasi kemampuan berfikir kreatif siswa pada kategori siswa yang memiliki minat belajar tinggi dan siswa yang memiliki minat belajar rendah agar dapat mengetahui kebenaran bahwa kemampuan berfikir kreatif siswa secara statistic terdapat perbedaan. Berikut ini disajikan data komparasi kedua factor minat belajar tersebut dengan SPSS 24.

Tabel 8

Komparasi Minat Belajar

Pairwise Comparisons

Dependent Variable: Kemampuan Berfikir Kreatif

\begin{tabular}{|c|c|c|c|c|c|c|}
\hline \multirow{2}{*}{$\begin{array}{l}\text { (I) } \\
\text { Kategori } \\
\text { Minat }\end{array}$} & \multirow{2}{*}{$\begin{array}{l}(\mathrm{J}) \\
\text { Kategori } \\
\text { Minat }\end{array}$} & \multirow{2}{*}{$\begin{array}{c}\text { Mean } \\
\text { Difference } \\
(\mathrm{I}-\mathrm{J})\end{array}$} & \multirow[b]{2}{*}{$\begin{array}{l}\text { Std. } \\
\text { Error }\end{array}$} & \multirow[b]{2}{*}{ Sig. ${ }^{\mathrm{b}}$} & \multicolumn{2}{|c|}{$\begin{array}{l}95 \% \text { Confidence } \\
\text { Interval for Difference }\end{array}$} \\
\hline & & & & & $\begin{array}{l}\text { Lower } \\
\text { Bound }\end{array}$ & $\begin{array}{l}\text { Upper } \\
\text { Bound }\end{array}$ \\
\hline Tinggi & Rendah & $3,692^{*}$ & ,624 & 000 & 2,446 & 4,938 \\
\hline Rendah & Tinggi & $-3,6$ & ,624 & 000 & $-4,938$ & $-2,446$ \\
\hline \multirow{2}{*}{ Mean } & Rendah & 14,648 &, 390 & - & 13,870 & 15,426 \\
\hline & Tinggi & 10,956 & 457 & - & 10,043 & 11,869 \\
\hline
\end{tabular}

Based on estimated marginal means

*. The mean difference is significant at the, 05 level.

b. Adjustment for multiple comparisons: Least Significant Difference (equivalent to no adjustments). 
Berdasarkan hasil uji komparasi tentang kemampuan berfikir kreatif pada kategori siswa yang memiliki minat belajar tinggi dan siswa yang mmemiliki minat belajar rendah dapat dilihat bahwa perbandingan minat tinggi dengan minat rendah menunjukan nilai signifikansi 0,000 yang berarti secara statistic terdapat perbedaan mean kemampuan berfikir kreatif siswa pada kedua faktor $(\mathrm{A} \neq \mathrm{B})$. Hal ini dapat terjadi karena rata-rata kemampuan berfikir kreatif siswa pada kategori minat tinggi sebesar 14,648 sedangkan rata-rata kemampuan berfikir kreatif pada kategori minat rendah sebesar 10,956, berdasarkan skor mean kedua faktor yang ditunjukan secara statistic memang menunjukan mean yang berbeda. Jadi secara statistic uji hipotesis ini menunjukan bahwa hipotesis nol (Ho) yang menyatakan bahwa kemampuan berfikir kreatif siswa yang memiliki minat tinggi dan siswa yang memiliki minat rendah sama $(A=B)$ yang berarti tidak terdapat pengaruh minat belajar siswa yang dikategorikan minat tinggi dan minat rendah terhadap kemampuan berpikir kreatif siswa dinyatakan ditolak dan hipotesis alternative (Ha) yang menyatakan bahwa kemampuan berfikir kreatif siswa yang memiliki minat tinggi dan siswa yang memiliki minat rendah berbeda $(A \neq B)$ yang berarti terdapat pengaruh minat belajar siswa yang dikategorikan minat tinggi dan minat rendah terhadap kemampuan berpikir kreatif siswa dinyatakan diterima dan digunakan. Temuan ini sejalan dengan hasil penelitian Tambunan (2016) yang menyatakan bahwa "terdapat pengaruh minat terhadap bberfikir kritis hal ini ditunjukan oleh kemampuan berpikir kreatif siswa yang memiliki minat tinggi lebih tinggi daripada siswa yang memiliki minat belajar rendah" selanjutnya juga sejalan dengan pendapat Frihatini (2017) yang menyatakan bahwa terdapat pengaruh minat belajar pada kategori minat tinggi dan minat rendah terhadap berfikir kreatif, yang dilihat dari perbedaan berfikir kreatif dari kedua metode tersebut.

\section{PENUTUP}

Secara umum, dari hasil penelitian dapat disimpulkan bahwa minat belajar dengan kategori minat belajar tinggi dan minat belajar rendah dapat dijadikan pertimbangan dalam menentukan penggunaan metode pembelajaran dan sangat menentukan kemampuan berpikir kreatif siswa. Secara khusus, berdasarkan rumusan masalah dan hipotesis penelitian yang diajukan serta hasil analisis data penelitian dan pembahasan yang dikemukakan, maka dapat ditarik kesimpulan bahwa terdapat pengaruh minat belajar siswa yang dikategorikan minat tinggi dan minat rendah terhadap kemampuan berpikir kreatif siswa dalam mata pelajaran prakarya dan kewirausahaan. Atau terdapat perbedaan yang signifikan kemampuan berfikir kreatif siswa dalam mata pelajaran prakarya dan kewirausahaan pada siswa yang memiliki karakteristik minat belajar tinggi dan siswa yang memiliki karakteristik minat belajar rendah.

\section{DAFTAR PUSTAKA}

\section{Sumber Buku}

Anderson, L. W. (2010). Kerangka Landasan untuk Pembelajaran, Pengajaran, dan Aesmen (Revisi Taksonomi Bloom). Yogyakarta: Pustaka Pelajar.

Asep Herry Hernawan, d. (2006). Pengembangan Kuri ku lum dan Pembelajaran . Jakarta: UT Departemen Pendidikan Nasional.

Filsaime, T. (2008 ). Menguak Rahasia Berpikir Kreatif dan Kreatif. Jakarta: Prestasi Pustaka. Hidayat, R. \&. (2013). Pendidikan Abad 21 dan Kuri kulum 2013. Unpak.

Martinis, Y. (2008). Paradigma Pendidikan Konstruktivistik. Jakarta: Gaung Persada Press.

Sbderstrbrm, T. F. (2011). From distance to online education: Educational management in the 21th century. Annual Conference Dublin.

Trilling, B. a. (2009). 21st Century Skills: Learning for Life in Our Times. San Fransisco, California: Jossey-Bass/John Wiley \& Sons, Inc.

Utami, M. (2009). Pengembangan Kreativitas Anak Berbakat. Jakarta: PT Rineka Cipta 


\section{Sumber Jurnal}

Almujab, S. (2015). Pengaruh Metode Discovery Terhadap Peningkatan Berpikir Kreatif (Studi Kuasi Eksperimen Mata Pelajaran Kewirausahaan Pada Siswa Kelas XI PS SMKN 1 Bandung).

Edora. (2015). Pengaruh Metode Pembelajaran Problem Based Learning Terhadap Peningkatan Kemampuan Berpikir Kritis Peserta Didik. Oikos Jurnal Pendidikan Ekonomi FKIP Unpas.

Gary Coombs, M. E. (2004). Education Introduction To The Special Issue: Problem-Based Learning As Social Inquiry-Pbl And Management. Journal Of Management Education Sage Publication, 28(5), 523-535.

Komara, Endang. (2018) Penguatan Pendidikan Karakter dan Pembelajaran Abad 21. SIPATAHOENAN: South-East Asian Journal for Youth, Sports \& Health Education. Volume 4 (1).

Kusumaningtias, A., Zubaidah, S., \& Indriwati, S. E. (2013). Pengaruh Problem Based Learning Dipadu Strategi Numbered Heads Together Terhadap Kemampuan Metakognitif, Berpikir Kritis, dan Kognitif Biologi Siswa Kelas Xi SMA Negeri 5 Malang. (Tesis). Disertasi dan Tesis Program Pascasarjana UM, 33-47. Retrieved From Http://Jpk.Lemlit.Um.Ac.Id/Wp-Content/Uploads/2014/08/02-Anyta-KusumaningtyasOk.Pdf

Muldayanti, N. D. (2013). Pembelajaran Biologi Model STAD dan TGT Ditinjau dari Keingintahuan dan Minat Belajar Siswa. JPII, 1 (1), 12-17. Https://Doi.Org/10.15294/Jpii.V4i2.4179

Nurina Happy, D. B. W. (2014). Keefektifan PBL Ditinjau Dari Kemampuan Berpikir Kritis dan Kreatif Matematis, Serta Self-Esteem Siswa SMP, 1(November), 176-187.

Prihatini, Effiyati (2017). Pengaruh Metode Pembelajaran dan Minat Belajar Terhadap Hasil Belajar IPA. Jurnal Formatif 7(2): 171-179, ISSN: 2088-351X

Redhana, I Wayan. A. A. Istri Agung Rai Sudiatmika, I Ketut Artawan. (2009) Pengembangan Perangkat Pembelajaran Berbasis Masalah dan Pertanyaan Socratik untuk Meningkatkan Keterampilan Berpikir Kritis Siswa SMP. Jurnal Pendidikan dan Pengajaran, Jilid 42, Nomor 3, Oktober 2009, hlm. 151 -159

Tambunan, Nurma. (2016). Pengaruh Strategi Pembelajaran dan Minat Belajar Terhadap Kemampuan Berpikir Kreatif Matematis Siswa. Jurnal Formatif 6(3): 207-219, 2016 ISSN: 2088-351X

Wiyono, K., Pd, S., Setiawan, A., Si, M., Suhandi, A., \& Si, M. (2009). “ Model Pembelajaran Multimedia Interaktif Relativitas Khusus untuk Meningkatkan Keterampilan Berpikir Kritis Siswa SMA. Makalah Seminar Nasional Pendidikan di FKIP Universitas Sriwijaya Palembang , 14 Mei 2009 Oleh :, 1-12.

\section{Sumber Lain}

Dwi, Laksana S. (2018). Integrasi Empat Pilar Pendidikan (Unesco) Dan Tiga Pilar Pendidikan Islam.

https://data.go.id/dataset/nilai-rata-rata-sekolah-un

Kemendikbud. (2016). Revitalisasi Pendidikan Vokasi.

Litbang. (2013). Kemendikbud. 